\title{
Böbrek Hücrelerinin Elde Edilmesinde Üç Farklı Primer Kültür Yönteminin Karşılaştırılması
}

\section{Comparison of Three Different Primary Culture Methods for Obtaining Kidney Cells}

\author{
Melek Pehlivan ${ }^{1}$, H.Seda Vatansever ${ }^{2,3}$, Burcu Çerçi ${ }^{4}$, Damla Akoğullar1², Yusuf Özlem İlbay ${ }^{5}$, İbrahim Pirim ${ }^{4 *}$ \\ ${ }^{1}$ İzmir Katip Çelebi Üniversitesi, Sağlık Hizmetleri Meslek Yüksekokulu, İzmir, Türkiye. \\ ${ }^{2}$ Manisa Celal Bayar Üniversitesi, Tıp Fakültesi, Histoloji-Embriyoloji AD, Manisa, Türkiye. \\ ${ }^{3}$ Yakın Doğu Üniversitesi, DESAM Araştırma Enstitüsü, Lefkoşa, KKTC. \\ ${ }^{4}$ İzmir Katip Çelebi Üniversitesi, Tıp Fakültesi, Tıbbi Biyoloji AD, İzmir, Türkiye. \\ ${ }^{5}$ Sağlık Bilimleri Üniversitesi, İzmir Tepecik EAH, Üroloji Kliniği, İzmir, Türkiye. \\ e-mail: pehlivanmlk@gmail.com, hsedavatansever@gmail.com, burcucerci35@gmail.com, \\ daakogullari@gmail.com, ozlemyusufilbey@hotmail.com, İbrahim.pirim@gmail.com \\ ORCID: 0000-0001-8755-4812 \\ ORCID: 0000-0002-7415-9618 \\ ORCID:0000-0002-7477-1073 \\ ORCID:0000-0001-9778-8532 \\ ORCID:0000-0002-1483-9160 \\ ORCID:0000-0001-8485-3286
}
*Sorumlu Yazar / Corresponding Author: İbrahim Pirim
Gönderim Tarihi / Received: 02.03.2021
Kabul Tarihi / Accepted: 17.05.2021
DOI: $10.34087 /$ cbusbed.886995

\begin{abstract}
Giriş ve Amaç: Böbrek hücrelerinin elde edilmesinde kullanılan primer kültür yöntemi, böbrek hastalıklarının hücre düzeyinde değerlendirilmesi ve hücre fonksiyonlarının incelenmesi için olanak sağlamaktadır. Bu çalışmanın amacı böbrek primer kültürü için kullanılabilecek üç farklı izolasyon yönteminin hücre sağkalımı ve protokol etkinliği açısından birbirleriyle karşılaştırılmasıdır.

Gereç ve Yöntemler: Nefrektomi ile çıkarılan böbrek dokusu steril şartlarda mekanik, tripsin ve kollajenaz yöntemi ile ayrımlanarak podosit vasatı içerisinde kültüre edildi. Kültüre edilen hücrelerin podosin, vimentin, E-kaderin, TGF$\beta 1$, CD133, ZO-1 ve Nefrin dağılımlarının analizi immünositokimyasal yöntem ile yapıldı.

Bulgular: Kollajenaz enzimatik yöntemi sonrasında hücrelerin kültürün 7. gününden itibaren, mekanik yöntemde ise 13. günden itibaren epiteloid karakter aldıkları gözlenirken, tripsin enzimatik yönteminde 13. günde kültürde artan fuziform yapıdaki hücreler gözlendi. Her üç yöntem ile böbrek dokusundan elde edilen podosit hücrelerin immunositokimyasal analizi sonrasında, elde edilen hücrelerde vimentin, E-kaderin, TGF- $\beta 1$, CD133, ZO-1 immunoreaktiviteleri farkl1lık gösterir iken, podosin ve nefrin immunoreaktivitelerinin kollajenaz enzimatik yöntemi ile elde edilen hücrelerde kuvvetli olduğu saptandı.

Sonuç: Bu çalışmada, farklı proteinlerin immunositokimyasal boyamaları ile kontrol edilen böbrek hücreleri için üç farklı primer kültür teknikleri karşılaştırıldığında, kollajenaz ile muamele edilen böbrek dokusundan daha yüksek verimle hücre saflaştırılabildiği gözlendi. Podosit hücrelerinin kültüre edilmesinde hücre sağkalım verimi ve protokol etkinliği açısından kollajenaz yönteminin en uygun yöntem olduğu gösterildi.
\end{abstract}

Anahtar Kelimeler: Böbrek primer kültürü, Kollajenaz, Mekanik, Tripsin. 


\begin{abstract}
Objective: The primary culture method used to obtain kidney cells provides an opportunity for evaluating kidney diseases at the cellular level and examining cell functions. The aim of this study is to compare three different isolation methods that can be used for kidney primary culture in terms of cell survival and protocol effectiveness.

Materials and Methods: Renal tissue removed by nephrectomy was separated by mechanical, trypsin and collagenase method in sterile conditions and cultured in podocyte medium. The distribution of podosin, vimentin, E-cadherin, TGF- $\beta 1$, CD133, ZO-1 and Nephrin analysis of the cultured cells was done by immunocytochemical method.

Results: It was observed that after the collagenase enzymatic method, the cells acquired epithelioid character from the 7th day of the culture and after the mechanical method from the 13th day of culture. In the trypsin enzymatic method, the cells with increased fusiform structure were observed in the culture on the 13th day. After the immunocytochemical analysis of podocyte cells obtained from kidney tissue with all three methods, it was detected that the immunoreactivities of vimentin, E-cadherin, TGF- $\beta 1$, CD133, ZO- 1 differ in the cells obtained. In addition, podosin and nephrine had strong immunoreactivities in cells obtained by collagenase enzymatic method.

Conclusion: In this study, it was observed that when three different primary culture techniques were compared for kidney cells controlled by immunocytochemical staining of different proteins, cells could be purified with higher yields from collagenase treated kidney tissue. Collagenase method was shown to be the most suitable method in terms of cell survival and protocol efficiency in culturing podocyte cells.
\end{abstract}

Keywords: Collagenase, Kidney primary culture, Mechanics, Trypsin.

1. Giriş
Akut böbrek hasarı, son dönem böbrek hastalığına doğrudan sebep olabilmekte, kronik böbrek hasarının gelişme riskini de arttırmaktadır. Her yıl dünyada 2 milyon kişi akut böbrek hasarının neden olduğu hastalıklardan ötürü hayatını kaybetmektedir [1]. Bunun yanı sıra kronik böbrek hastalıkları ve son dönem böbrek yetmezliği olan hastaların çoğu için diyaliz gereklidir ve en kesin tedavi yöntemi organ naklidir [2].

İnsan böbrek hücrelerinin kültüre edilmesi, böbrek hastalıkları ve böbrek hücre fonksiyonlarındaki biyokimyasal ve patolojik değişimlerin belirlenebilmesi için çok önemlidir [3]. Böbrekler karın duvarında bulunurlar. Her bir böbrek, yaklaşık 1 milyon nefrondan meydana gelmektedir. Nefronlar temel olarak filtrasyonun gerçekleştiği renal korüpkül ve tübül kısmından oluşmaktadır. Renal korpüskülleri oluşturan kapiller kıvrım glomerulus bowman kapsülünün içine yerleşmiş durumdadır. Glomerulustaki kan, bowman kapsülünden gelen siviyla bir filtrasyon bariyeri sayesinde ayrılır. $\mathrm{Bu}$ filtrasyon bariyeri tek hücreli kapiller endoteli, hücresiz, protein içeren bazal lamina ve Bowman kapsülünde uzanan tek sıralı epitel hücrelerden oluşur. Bowman kapsülündeki epitel hücreler podositler olarak isimlendirilirler. Kapiller, endotel ve podosit hücrelerine ek olarak glomerular kapilleri saran ve mezangiyal hücre adı verilen düz kas hücreleri de bulunmaktadır [4].

Temelde böbrek hücrelerini elde edebilmek için üç farklı kültür yöntemi bulunmaktadır. İlki, böbrek orjinli hayvan hücre hatlarının kullanılmasına dayanır. Çalışılması kolay olsa da insan fizyolojisini bire bir gösteremeyecek olması çalışmaları kısıtlamaktadır. İkinci yaklaşım diseksiyonla hücrelerin eldesidir. Primer kültür ile elde edilen hücreler klonlanarak tek bir hücre tipi elde edilir. $\mathrm{Bu}$ yöntemle, büyütülen hücre sayısında kayıplar yaşanmaktadır. Üçüncü yöntem ise, böbrek dokusunun çıkarılıp parçalanmasına, serumsuz, hormonal olarak tanımlı ve kontrol altında tutulan bir kültür ortamında büyütülmesine dayanır. Bu yöntem sayesinde istenilen hücrelerin büyümesi sağlanırken, diğer hücre gruplarının gelişmesi engellenebilir [5]. Hücrelerin kültürlenmesi için, öncelikle hücrelerin hücre bazal membranından veya hücre matris bağlantılarından ayrılmaları gerekmektedir. Hücrelerin ayrılmasında, enzimatik, kimyasal sindirim yöntemleri veya mekanik ayırma yöntemleri kullanılmaktadır [6].

$\mathrm{Bu}$ yöntemlerin kendi içerisinde avantaj ve dezavantajları bulunmaktadır. Örn: Mekanik yöntem, ilk yıkama aşamalarında kırmızı kan hücrelerinin ortamdan uzaklaştırılması için iyi bir yöntemdir ancak her ne kadar doku küçük parçalara bölünse de tek hücre süspansiyonu haline getirmek zordur. Ayrıca mekanik yöntem sonrasında kültüre edilen parçalardaki hücre çeşitliliği tek tip hücre elde edilmesinde ekstra ortamlar gerektirebilir. Kollajenazlar, kas hücre dışı matrisinin ana bileşeni olan kollajen içindeki peptit bağlarını hedefler. Çeşitli kollajenaz alt tipleri mevcuttur ve bunlar kazeinaz, klostripain veya tripsin gibi birkaç proteolitik yan aktivite içerebilirler. Tripsinizasyon ise kültürde hücre yüzeyi antijenlerini, hücre yüzeyi topografisini, hücre iskeleti bileşenlerini etkileyebilir bu da birincil kültürde, izolasyonda başarısızlığa neden olabilir. Bu ve benzeri etkiler, enzim partileri arasındaki litik aktivitenin değişkenliği, dokuların farklı kaynaklardan olması nedeniyle kollajenazlara ya da diğer enzimlere olan değişken duyarlılıkları, her izolasyon çalışmasında farklı doku örnekleri için değişmektedir; bu nedenle klinik kullanım için enzimatik izolasyon yönteminin doğrulanması zordur [7].

$\mathrm{Bu}$ çalışmada nefrektomi sonucunda çıkartılan böbrek dokusunda mekanik ve enzimatik yöntem ile kültür kurulmuştur. Enzimatik yöntem olarak tripsin ve kollajenaz ile mekanik yöntem olarak dokunun bistüri ile küçük parçalara ayrılması prosedürleri kullanılmış, 3 farklı izolasyon yönteminin primer 
kültür sonuçları karşılaştırılmıştır. Kültüre edilen hücrelerin karakterizasyonu immünositokimya ile gerçekleştirilmiştir.

\section{Materyal ve Metot}

Böbrek dokusu nefrektomi ile çıkarıldıktan sonra steril şartlar korunarak podosit kültür vasatı [\%20 fötal sığır serumu (FBS-11B, Capricorn), \%1 Lglutamin (GLN-B, Capricorn), \%1 penisilinstreptomisin (PS-B, Capricorn) içeren RPMI1640 (R8758; Sigma) içerisine alınarak 1 saat içerisinde Manisa Celal Bayar Üniversitesi Tıp Fakültesi Histoloji-Embriyoloji AD hücre kültürü laboratuvarına ulaştırıldı.

\subsection{Mekanik yöntem:}

Kültür vasatı içerisinden steril koşullar korunarak örnek, steril fosfat tampon solüsyonu (PBS, Merck) içeren petri içerisine alındı. Bistüri yardımıyla korteks ve medullası ayrıldıktan sonra hücre debrisi ve kanın uzaklaştırılması için 2 defa 5'er dakika PBS ile yıkandı. Temizlenen doku parçaları podosit kültür vasatı bulunan 6 gözlü kültür kabının 3 gözüne aktarıldı ve $\% 5 \mathrm{CO}_{2} 37^{\circ} \mathrm{C}$ 'de inkübasyona kaldırıldı. 2.2 Tripsin Yöntemi:

Dokunun korteks ve medullası ayrıldıktan sonra, bistüri yardımı ile küçük parçalara ayrılan örnekler, içerisinde $5 \mathrm{ml}$ tripsin-EDTA (SH30042.01, HyClone) bulunan petrilere alınd 1 ve 1 gece $+4{ }^{\circ} \mathrm{C}$ ' de inkübe edildi. Ertesi sabah soğuk tripsin uzaklaştırıldı ve dokuların üzerine $2 \mathrm{ml} 37^{\circ} \mathrm{C}$ ' ye 1 sıtılmış tripsinEDTA eklendi. Tüm örnekler 30 dakika $\% 5 \mathrm{CO}_{2}$ $37^{\circ} \mathrm{C}$ 'de inkübasyonun ardından tripsin-EDTA solüsyonu uzaklaştırıldı ve örnekler üzerine 5 'er ml podosit kültür vasatı ilave edilerek $1000 \mathrm{rpm}$ 'de $5 \mathrm{dk}$ santrifüj edildi. Yıkama işlemi 2 kere tekrarlandıktan sonra supernatant atıldı ve hücreler podosit kültür vasatı bulunan 6 gözlü kültür kabının 3 gözüne aktarıldı ve $\% 5 \mathrm{CO}_{2} 37^{\circ} \mathrm{C}$ 'de inkübasyona kaldırıldı. 2.3 Kollajenaz Yöntemi:

$\mathrm{Bu}$ yöntem için $\% 0,075 \mathrm{mg} / \mathrm{ml}$ olacak şekilde kollajenaz Tip I (C0130, Sigma) podosit kültür vasatı içerinde hazırlandı ve $0.22 \mu \mathrm{m}$ lik filtreden geçirildi. Doku parçalarının üzerine $15 \mathrm{ml}$ olacak şekilde eklendi ve 1 saat $37^{\circ} \mathrm{C}$ 'de inkübe edildi. Üzerine yaklaşı $1 \mathrm{ml}$ taze podosit kültür vasatı eklenerek kollajenaz inaktive edildi ve 15 ml'lik tüpe alınan sıvı kısım 1000 rpm'de 5 dk santrifüj edildi. Supernatant atıldı, $5 \mathrm{ml}$ podosit kültür vasatı eklendi ve 1000 rpm'de 5 dakika santrifüj edilerek yıkama işlemi tamamlandı. Hücreler podosit kültür vasatı bulunan 6 gözlü kültür kabının 3 gözüne aktarıldı ve $\% 5 \mathrm{CO}_{2}$ $37^{\circ} \mathrm{C}$ 'de inkübasyona kaldırıldı.

\subsection{Hücrelerin Pasajlanmasl}

Her üç yöntem ile 6 gözlü kültür kaplarında kültüre edilen örnekler her 2 günde bir kültür vasatları değiştirilerek \%80 konfluent olduklarında pasajlandı. $\mathrm{Bu}$ amaç için tüm örneklerdeki kültür vasatları alındı ve her bir gözde 1'er ml olacak şekilde tripsin-EDTA (SH30042.01, HyClone) ilavesi yapıldı ve hücreler $\% 5 \mathrm{CO}_{2} 37^{\circ} \mathrm{C}$ 'de $10 \mathrm{dk}$ inkübe edildi. Ardından her bir göze 1 'er ml podosit kültür vasatı ilave edilerek hücreler toplandı, $1000 \mathrm{rpm}$ de $5 \mathrm{dk}$ santrifüj edilerek hücrelerin bir kısmı stoklama amacı için 9 birim FBS ile 1 birim Dimetil Sülfoksit (DMSO) (A3672, AppliChem) kullanılarak hazırlanan dondurma vasatı içerisine alındı. Hücreler eş zamanlı olarak sıvı azot tankı ve $-80^{\circ} \mathrm{C}^{\prime}$ de saklandı. Toplanan diğer hücreler immunositokimya analizi için $12 \mathrm{~mm}$ lik FBS ile kaplanmış yuvarlak lamel içeren 24 gözlü kültür kaplarına her bir gözde $1 \times 10^{3}$ hücre olacak şekilde ekilerek kültür ișlemine devam edildi.

\subsection{Immünositokimyasal Boyama}

Böbrek hücreleri 24 gözlü kültür kaplarına ekimlerinden \%60-70 konfluent olduklar1 48. saatte $\% 4$ paraformaldehit (1.04004.0800, Merck, Darmstadt, Germany) ile 30 dakika oda sicaklığında fikse edildi. Hücreler fosfat tamponunda (PBS, PBS404.100, Bioshop, Ontario, Canada) 30 dakika boyunca iki kez yıkandıktan sonra hücre permeabilizasyonu için $+4^{\circ} \mathrm{C}$ 'de 15 dakika $\% 0,1$ Triton X-100 (A4025, Biomatic) ile muamele edildi. PBS ile 3 defa yıkanan hücreler endogen peroksidaz aktivitesini inhibe etmek için $\% 3 \quad \mathrm{H}_{2} \mathrm{O}_{2}$ (1.08597.2500, MERCK) ile 5 dakika oda sıcaklığında inkübe edildi ve ardından 3 defa 5 'er dakika PBS ile yıkandı. Tüm hücreler sekonder kit (AEN080, ScyTek) içinde kullanıma hazır olarak gelen bloklama solüsyonu ile 1 saat oda sıcaklığında inkübe edildi ve ardından direkt çekilerek primer antikorlar; anti-vimentin (rabbit polyclonal, 10366-1AP, Proteintech, CHINA, dilution:1/50), anti-Ekaderin (rabbit polyclonal, 20874-1-AP, Proteintech, CHINA, dilution:1/50), anti-TGF- $\beta 1$ (rabbit polyclonal, LS-B655, LifeSpan Biosciences, WA, USA, dilution:1/50), anti-CD133 (rabbit polyclonal, STJ20168, St John's Laboratory Ltd, London, UK, dilution:1/50), anti-ZO-1 (rabbit polyclonal, 61-7300, ThermoFisher Scientific, MA, USA dilution:1/10), anti-Nefrin (mouse monoclonal, 66970-1-Ig, Proteintech, CHINA, dilution: 1/2000) ve antiNPHS2 (podosin, rabbit polyclonal, 20384-1-AP, Proteintech, CHINA, dilution: 1/200) ilave edildi ve $4^{\circ} \mathrm{C}$ 'de bir gece inkübe edildi. PBS ile 3 defa 5 'er dakika yıkanan hücrelere sekonder kit içinde kullanıma hazır halde gelen biotinlenmiş goat anti rabbit/mouse IgG ve peroksidaz ile konjuge streptavidin ile 30'ar dakika inkübe edildi. İki sekonder kit arasında PBS ile yıkama gerçekleştirildi. İmmunositokimyasal reaksiyonun görünürlülüğünü sağlamak için hücreler diaminobenzidin (DAB, TA125-HD, ThermoFisher Scientific) ile 5 dakika boyandı ve ardından PBS ile 15 dakika yıkama işlemi gerçekleştirildi. Artalan boyaması için hücreler Mayer's hematoksilen (TA-125-MH, ThermoFisher Scientific) ile 1 dakika boyand 1 ve distile su ile 30 dakika yıkama işleminden sonra her bir gözde bulunan yuvarlak lameller $20 \mu \mathrm{l}$ kapatma solüsyonu (K002, Diagnostic Biosystems) bulunan lamlar üzerine alınarak 1şık mikroskobunda (Olympus BX43, Tokyo, JAPAN) gözlendi. İki bağımsız araştırmacı tarafından fotoğrafları çekilerek immün 
işaretleme yarı kantitatif olarak boyanma yoğunluğu negative (-), hafif $(+)$, orta (++) ve güçlü $(+++)$ olarak yorumland. Kontrol immunositokimyasal analiz için primer antikorlar basamağı yerine uygun IgG ilavesi yapılarak tüm protokol basamağı aynı şekilde uygulandı.

\section{Bulgular ve Tartışma}

\subsection{Hücre Kültürü}

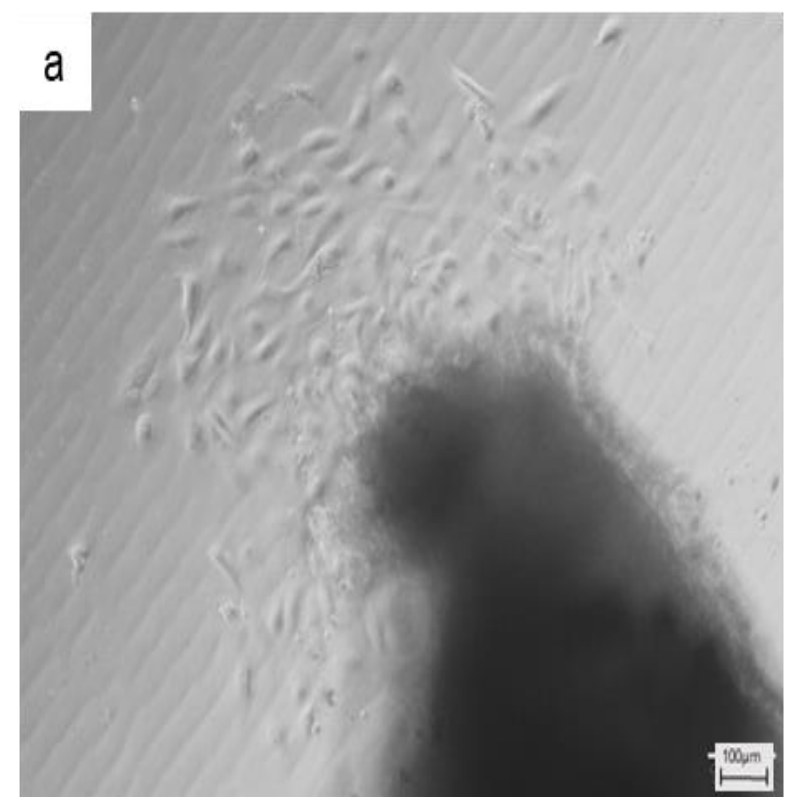

Podosit hücre eldesi amacı için mekanik ve enzimatik (kollajenaz ve tripsin) yöntem uygulamaları sonrasında kültüre edilen örnekler incelendiğinde, mekanik yöntem sonrasında kültürün 7. gününde hücreler dokuların kenarlarında gözlendi (Şekil 1a). Kültürün 13. gününde doku parçaları steril pens ile ortamdan alınarak kültüre devam edildiğinde hücrelerin epiteloid karakterde oldukları belirlendi (Şekil 1b).

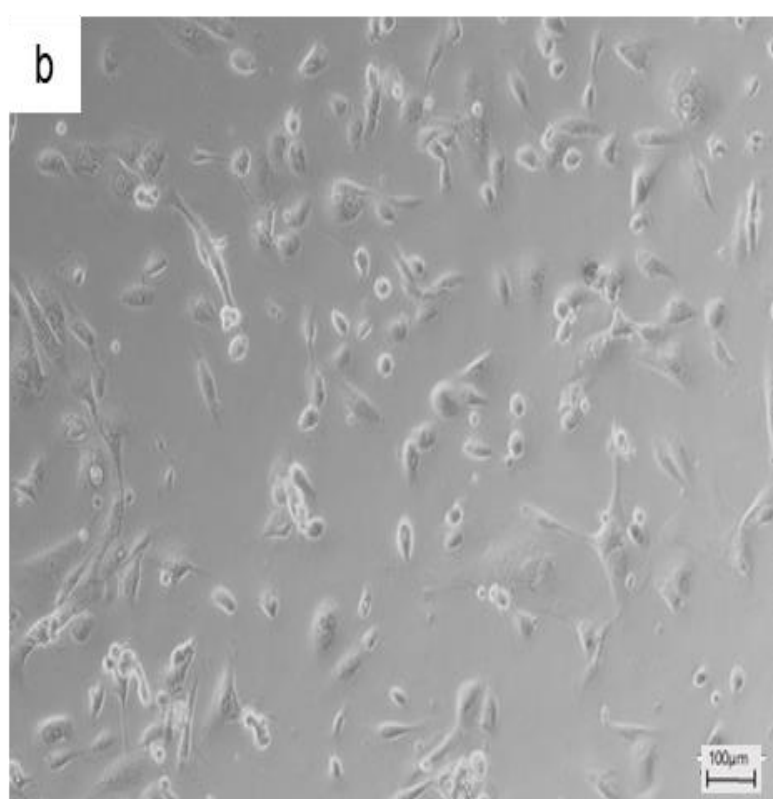

Şekil 1. Mekanik yöntem sonrasında Podosit Hücre kültürü a: 7. Gün, b: 13. Gün. Ölçek $100 \mu$ m
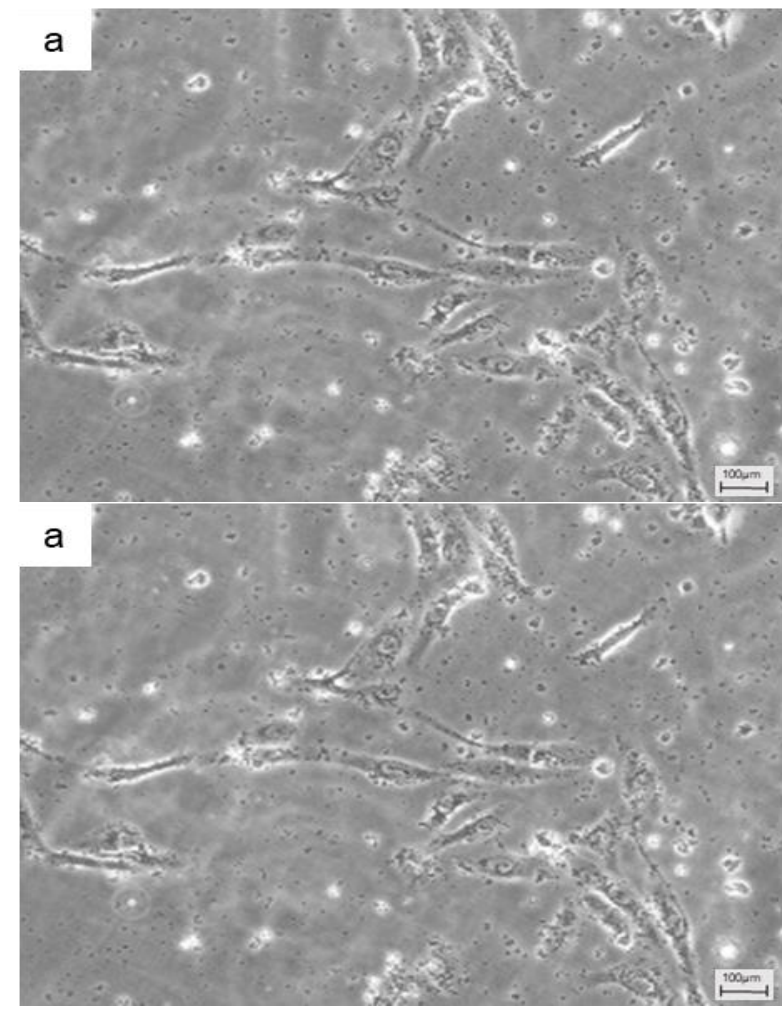

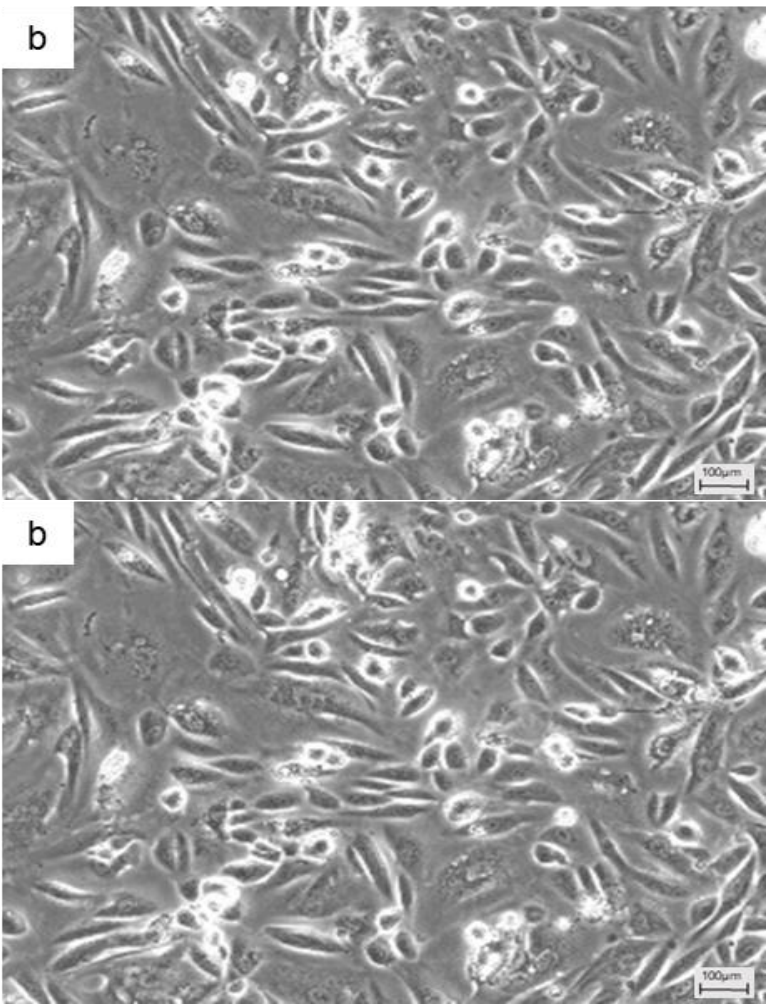

Şekil 2. Tripsin-EDTA enzimatik yöntemi sonrasında Podosit Hücre kültürü a: 7. Gün, b: 13. Gün. Ölçek $100 \mu \mathrm{m}$ 
Tripsin-EDTA enzimatik yöntemi sonrasında kültürün tripsinden kaynaklı kirli olduğu, fakat kültüre devam edildiğinde kültür vasatının temizlendiği (Şekil 2), fusiform yapıdaki hücrelerin kültürün 7. gününde az iken (Şekil 2a), kültürün 13. gününde arttığı gözlendi (Şekil 2b).
Kollajenaz enzimatik yöntemi sonrasında hücrelerin kültürün 7. gününden itibaren epiteloid karakterde oldukları (Şekil 3a), bu özelliklerini kültürün 13. gününde de devam ettirdikleri (Şekil 3b) gözlendi.
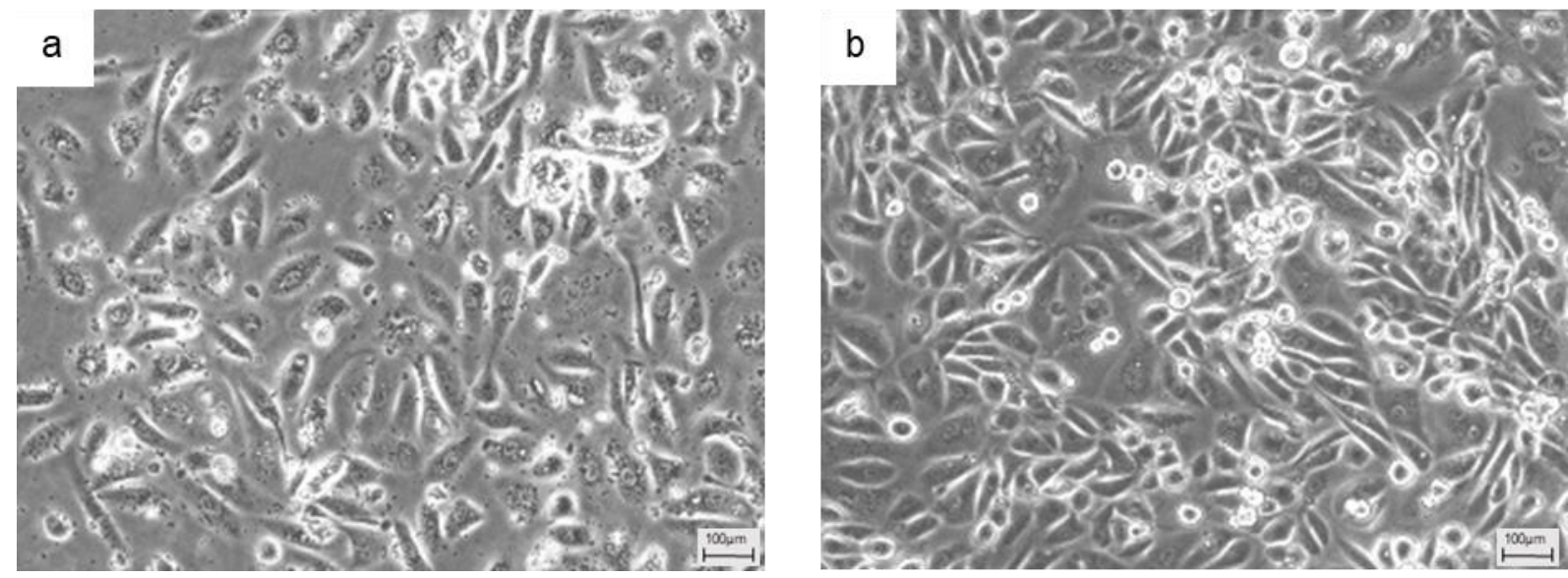

Şekil 3. Kollajenaz enzimatik yöntemi sonrasında Podosit Hücre kültürü a: 7. Gün, b: 13. Gün. Ölçek $100 \mu \mathrm{m}$

\subsection{Immunositokimya Bulgular}

Her üç yöntem ile böbrek dokusundan elde edilen podosit hücrelerin immunositokimyasal analizi sonrasında, mekanik yöntem ile elde edilen hücrelerde vimentin immunoreaktivitesi orta şiddette $(++)$ ve yer yer güçlü $(+++)$ iken (Şekil 4a), E-kaderin immunoreaktivitesinin zayıf $(+)$ ama yer yer orta şiddette $(++)$ olduğu gözlendi (Şekil $4 b)$. Aynı grup hücrelerde TGF- $\beta 1$ immunoreaktivitesi zayıf şiddette iken (Şekil 4c), CD133 immunoreaktivitesi orta $(++)$ ve yer yer güçlü $(+++)$ (Şekil 4d), ZO-1 immunoreaktivitesi orta şiddette $(++)$ (Şekil 4e) pozitif idi. Kontrol immunoreaktivite örneklerinde boyanma gözlenmedi (Şekil 4f).

Podosit hücrelerin immunositokimyasal analizi sonrasında, tripsin-EDTA enzimatik yönteminde vimentin (Şekil 5a) ve CD133 (Şekil 5d) immunoreaktiviteleri orta şiddette $(++)$ iken, Ekaderin (Şekil 5b), TGF- $\beta 1$ (Şekil 5c), ZO-1 (Şekil $5 \mathrm{e})$ ve kontrol (Şekil 5f) boyamalarında immunoreaktivite gözlenmedi. Podosit hücrelerin immunositokimyasal analizi sonrasında, kollajenaz ile enzimatik yöntem sonrasında vimentin immunoreaktivitesi orta şiddette $(++)$ ve yer yer güçlü $(+++)$ iken (Şekil 6A), E-kaderin immunoreaktivitesinin de orta $(++)$ ve yer yer güçlü $(+++)$ şiddette olduğu gözlendi (Şekil 6B). TGF- $\beta 1$ immunoreaktivitesi ise bu grup hücrelerde yer yer zayıf şiddette $(+)$ idi (Şekil 6C). CD133 immunoreaktivitesi ise güçlü $(+++)$ olarak saptanır iken (Şekil 6D), ZO-1 (Şekil 6E) ve kontrol (Şekil $6 \mathrm{~F})$ boyamalarda immunoreaktivite gözlenmedi.
Kültüre edilen hücrelerin hücresel ve immunositokimyasal boyanma özelliklerine göre kollajenaz enzimatik yöntemi uygulanan hücrelerde daha iyi olması üzerine bu hücrelerde yapılan NPHS2 ve Nephrin podosit belirteçlerinin immunositokimyasal analizi sonrasında her iki antikora ait boyamanın güçlü $(+++)$ pozitif olduğu ve kontrol immunositokimyasal boyamada da boyanmanın olmadığg gözlendi (Şekil 7).

Tartışma

Hücre kültürü, hücrelerin çok sayıda elde edilebilmesine ve tekrarlayan çalışmaların yapılabilmesine olanak sağlamaktadır. Fizyolojik ve toksikolojik çalışmalar için doku kesitleri, hücre hatları ve primer kültürler gibi birçok farklı yöntemle böbrek hücreleri incelenmektedir. Bunların arasında toksikoloji gibi bazı çalışma alanlarında hücre hatlarının kullanılması uygun olmamaktadır. İmmortalize hücre hatları pasajlamalar sonucunda farklılaşabilmekte ve orijinal karakteristikleri değişebilmektedir. Bu sebeple deney sonuçları etkilenebilmektedir. Primer hücre kültürleri ise fenotipik olarak orijinal dokunun fenotipik ve fizyolojik özelliklerini taşırlar. $\mathrm{Bu}$ sebeple gen çalışmaları, ilaç testleri ve biyobelirteç geliştirilmesi için primer kültürler en uygun modellerdir [8]. Farklı böbrek hücrelerinin ideal primer kültürleri için yapılan pek çok çalışma bulunmaktadır $[9,10]$. 

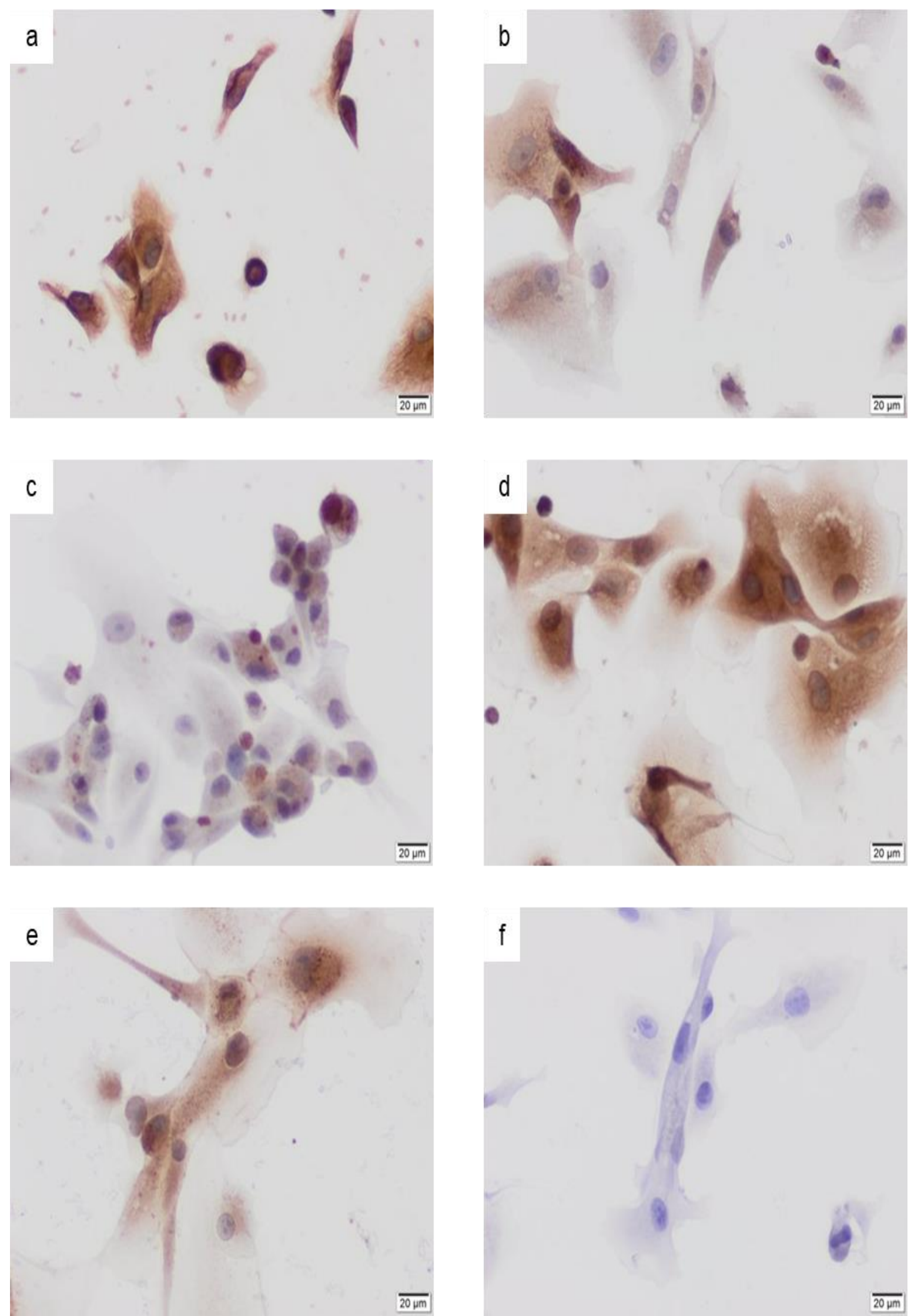

Şekil 4. Mekanik yöntem sonrasinda Podosit Hücre kültürü hücrelerinde Vimentin (a), E-kaderin (b), TGF- $\beta 1$ (c), CD133 (d), ZO-1 (e) ve kontrol immunositokimya (f) boyamaları. Ölçek $20 \mu \mathrm{m}$ 

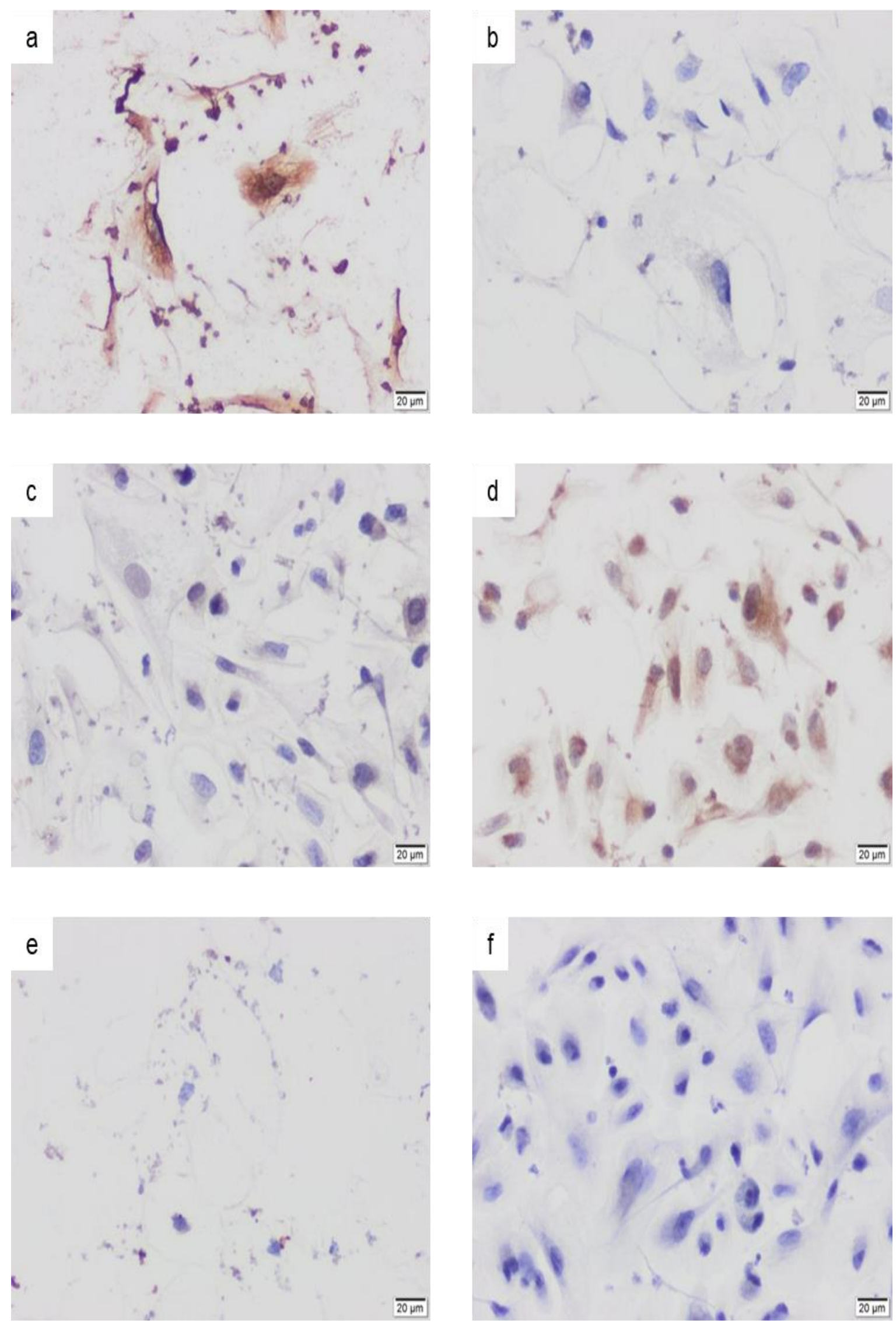

Şekil 5. Tripsin-EDTA enzimatik yöntemi sonrasında Podosit Hücre kültürü hücrelerinde Vimentin (a), Ekaderin (b), TGF- $\beta 1$ (c), CD133 (d), ZO-1 (e) ve kontrol immunositokimya (f) boyamaları. Ölçek $20 \mu \mathrm{m}$ 

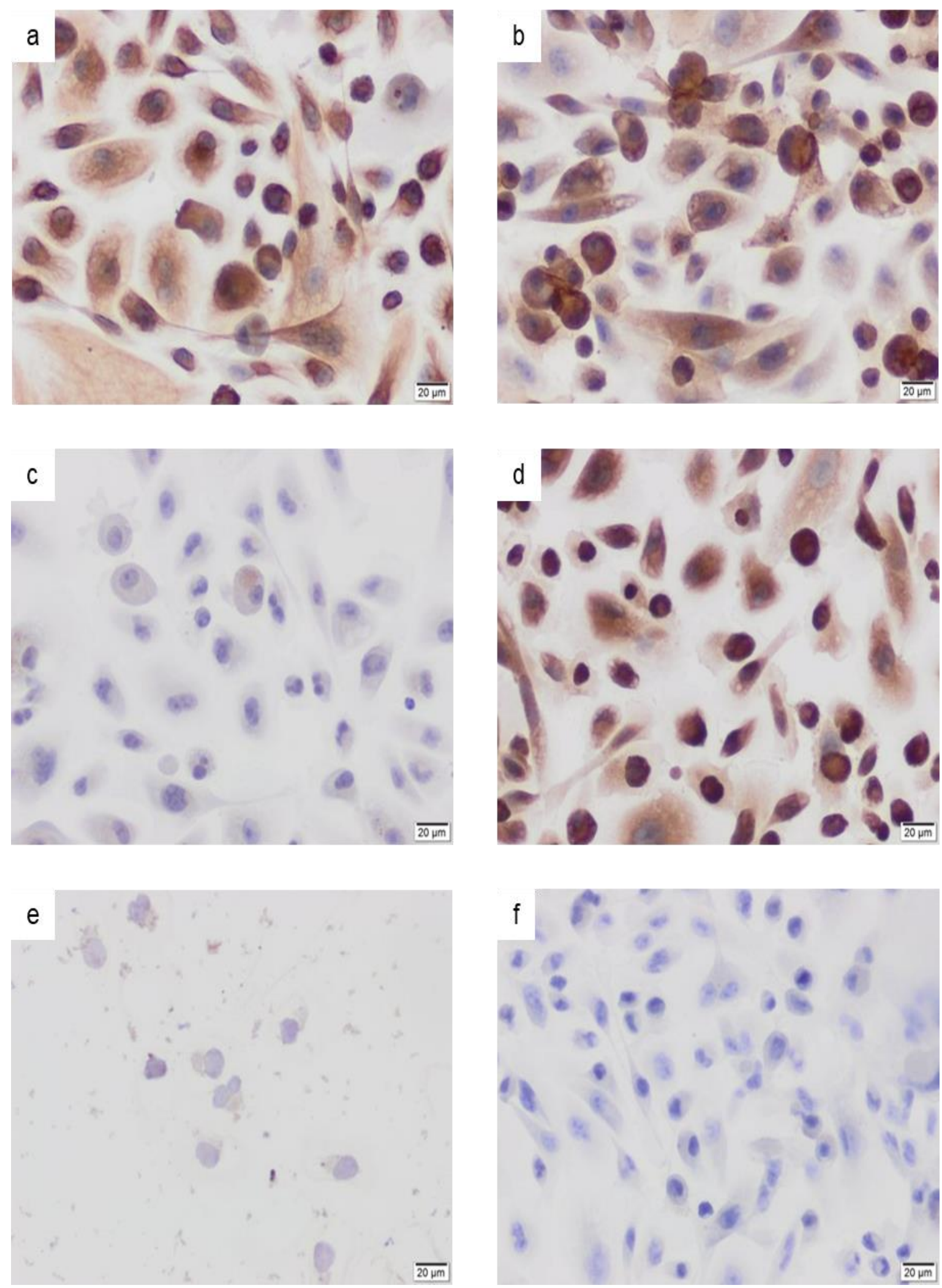

Şekil 6. Kollajenaz enzimatik yöntemi sonrasında Podosit Hücre kültürü hücrelerinde Vimentin (a), E-kaderin (b), TGF- $\beta 1$ (c), CD133 (d), ZO-1 (e) ve kontrol immunositokimya (f) boyamaları. Ölçek $20 \mu \mathrm{m}$ 

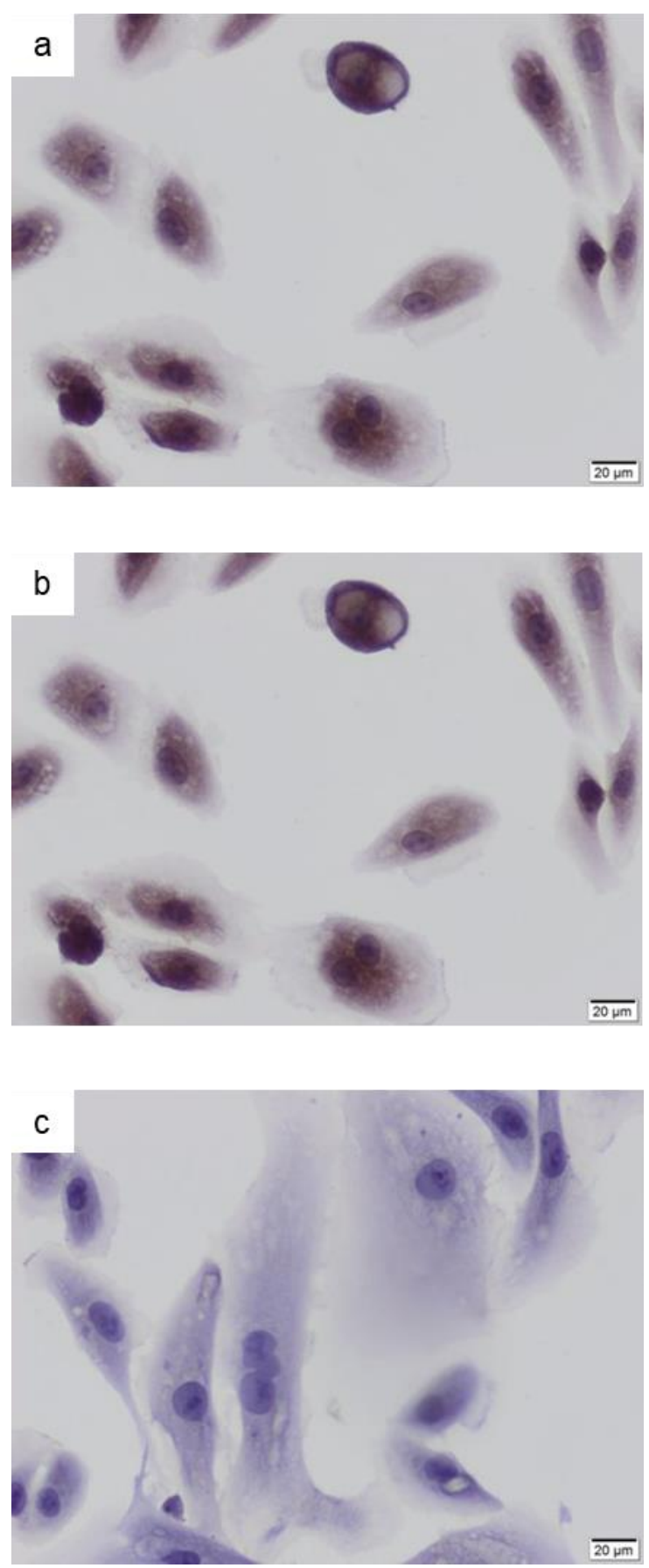

Şekil 7: Kollejenaz Enzimatik Yöntemi Sonrasında Podosit Hücre Kültürü hücrelerinde NPHS2 (a), Nefrin (b) ve kontrol immunositokimya (c) boyamaları. Ölçek $20 \mu \mathrm{m}$

$\mathrm{Bu}$ çalışmada, nefrektomi işlemi olan hastanın böbreğinin sağlıklı dokusundan alınan örnek ile, primer hücre kültürü için kullanılan üç farklı yöntem karşılaştırılarak podosit hücre eldesinde hangi yöntemin daha verimli olabileceği incelendi. Primer kültür aşamasında en önemli faktör örneğin olabilecek en kısa süre içerisinde kültüre alınmasıdır [11]. Bu sebeple nefrektomiden sonraki ilk 1 saat içinde böbrek dokusu laboratuvarda kültüre edildi. Kültür işlemi sırasında her üç yöntem ile de hücrelerin elde edilebildiği gözlendi. Mekanik ve kollajenaz enzimatik yöntemi sonrasında epiteloid karakterde hücrelerin elde edilmesi üzerine bu iki yöntemin, tripsin-EDTA enzimatik yöntemine göre podosit hücre eldesinde daha uygun olduğu düşünüldü. Kollajenaz enzimatik yöntemi sonrasında kültürün erken dönemlerinde elde edilen hücre sayısının mekanik yöntem ile elde edilen hücrelere oranla daha fazla olmasından dolayı primer kültür aşamasında kollajenaz enzimatik yönteminin daha uygun olduğu sonucuna varıldı.

Böbrek hücrelerinin immünositokimyasal analizi sonrasında öncelikli olarak hücreler arası bağlantı proteinlerinin varlığının analizi hedeflenmişti. Glomerulus fonksiyonunun bozukluğu ve filtrasyon kapasitesindeki azalıș son dönem böbrek hasarının temel sebebidir. Otoimmün hastalıklar, bakteriyel endokardit, HIV, diyabet, hipertansiyon gibi birçok hastalıkta glomerulus fonksiyon bozukluğuna bağlı böbrek hasarı görülmektedir. Böbrekteki filtrasyon bariyeri, suda çözünebilir moleküllerin geçişine izin verirken büyük makromoleküllerin geçişine izin vermezler. Filtrasyon bariyerinin bu seçici geçirgenliği P-kaderin, okludin, ZO1, nefrin, podosin ve CD2AP gibi hücreler arası bağlantı proteinleri ile düzenlenmektedir [12)]. Vimentin ara filament proteinidir ve insanlarda normal mezenkimal hücrelerde ifade edilir [13]. Uzun yıllardır yapılan çalışmalarda vimentin ve kaderin ailesi üyelerinden Ekaderin normal ve kanserli renal hücrelerin tanısında kullanılmıştır [14]. TGF- $\beta$, çok fonksiyonlu bir sitokindir ve büyüme, farklılaşma, apoptoz, yara onarımı gibi farklı hücresel süreçlerde görev almaktadır. Birçok böbrek hücresinde ekstraselüler matriks proteinlerinin üretimini indüklediği belirlenmiştir. Ayrıca renal inflamasyon ve renal fibrozda da rol oynadığ sağlıklı yetişkin insan böbreğindeki renal progenitör hücrelerde ifade edilen bir yüzey belirtecidir. Bu hücreler endotel veya epitel hücrelere farklılaşabilir, kendini yenileyebilir. CD133+ olan hücreler renal korteks, intersitiyal bölge ve glomerulusta bulunabilir. Bu sebeple CD133 belirteci normal böbrek dokusundaki hücrelerin tanımlanması için kullanılabilmektedir [16]. Çalışmamızda, immünositokimyasal analiz sonrasında ZO-1 immunoreaktivitesi mekanik yöntem ile elde edilen hücrelerin her iki enzimatik yöntem ile elde edilen hücrelere nazaran daha fazla olması, enzimatik yöntem sırasında sıkı bağlantı komplekslerin yapısında bozulmaya neden olabileceğini düşündürdü. TripsinEDTA enzimatik yöntemi sonrasında sadece vimentin ve CD133 immunoreaktiviteleri olduğu saptanmış ve bu iki proteine ait immunoreaktivitelerinde diğer yöntemler ile elde edilen hücrelerden daha az olması tripsin-EDTA enzimatik yönteminin podosit hücre eldesinde uygun olmayabileceği sonucuna varılmıştır. Kollajenaz enzimatik yöntemi sonrasında ZO-1 dışında diğer tüm proteinlere ait immunoreaktivitelerin mekanik yöntem ile elde edilen hücrelerden daha fazla olması, böbrekten primer kültür sonrasında hücre elde edilmesinde en 
uygun yöntemin kollajenaz enzimatik yöntemi olduğu sonucuna varılmıştır. Valente ve ark. yaptıkları çalışmada da kollajenaz sindiriminin epitelyal hücreler için diğer enzimlerle (tripsin olarak) sindirimden daha az zararlı olduğu, normal ve kanserli renal primer hücre kültüründe, daha yüksek verim ve canlılığa sahip hücre süspansiyonları oluşturduğunu belirtmiştir [12]. Elde edilen sonuçlara göre, böbrek hücrelerinin kültüre edilebilmesi için kollajenaz uygulanmasının, tripsin ve mekanik parçalamaya göre daha uygun bir yöntem olduğu belirlenirken, podosit hücrelerinin varlığının tespiti için yapılan NPHS2 (podosin) ve nefrin immunositokimya analizleri sonrasında her iki belirtecin de güçlü bir şekilde boyandığ 1 ve kollajenaz enzimatik yöntemi sonrasında primer böbrek kültüründe podositlerin elde edilebildiği sonucuna varıldı. Yapılan araştırmalarda primer hayvan podosit kültürlerinin kullanımı ile insandaki normal böbrek fonksiyonu ve glomerular hastalıklarla ilgili modeller oluşturulmaktadır. Fakat türler arasındaki farklılıklar insan podositlerinin fonksiyonel, yapısal ve moleküler hasarının belirlenmesinde kısıtlı kalmaktadır. Bu yüzden insan kaynaklı podositlerin çalışmalarda kullanılması böbrek araştırmalarında ve yeni tedavi stratejilerinin geliştirilmesinde oldukça önemlidir [12]. Ancak in vivoda podositler tipik olarak çoğalmazlar. Proliferatif olmayan terminal farklılaşmış ve oldukça özelleştirilmiş bir fenotipi çoğaltmak için, özel hücre kültürü şartları gereklidir. Çok sayıda podosit hücresi üretmek için, hücrelerin öncelikle büyümeye izin veren koşullar altında büyütülmesi gerekmektedir [17].

\section{Sonuç}

Primer hücre kültürleri, orijinal dokunun taklit edilmesindeki en uygun yöntemlerden biridir. Özellikle ticari hücre hatlarının pahalı olması yanı sıra böbreğin fonksiyonel kısımlarından elde edilen primer insan hücreleri kişiye özel deneysel çalışmalar ile pek çok toksikolojik veya genomik çalışmada kullanılabilir. Bu çalışmada, literatürde bulunan farklı primer kültür tekniklerinden üçünün karşılaștırılması sonrasında kollajenaz ile muamele edilen böbrek dokusundan daha yüksek verimle hücre saflaştırılabileceği gözlendi. Sonuçlarımız, farklı proteinlerin immunositokimyasal dağılımları incelenerek böbrek hücrelerinin tanımlanmasında ve podosit hücrelerinin kültüre edilmesinde protokol etkinliği ve hücre sağkalım verimi açısından kollajenaz yönteminin en uygun yöntem olduğunu göstermektedir.

\section{Referanslar}

1. Chawla, Lakhmir S, Paul, L.K, Acute kidney injury and chronic kidney disease: an integrated clinical syndrome, Kidney international, 2012, 82(5), 516-524.

2. Levey, A.S, Cassandra, B.B, Lesley, A.I, Glomerular filtration rate and albuminuria for detection and staging of acute and chronic kidney disease in adults: a systematic review, JAMA, 2015, 313(8), 837-846.

3. Ding, W, Keyvan, Y, Lina, A.S, Isolation, characterization, and high throughput extracellular flux analysis of mouse primary renal tubula epithelial cells, Journal of visualized experiments JoVE, 2018, 136.
4. Vander, A.J, Sherman, J.H, Luciano, D.S, The mechanism of body function. In: Vander's human physiology, McGraw-Hill Education, 2000, pp 476-486.

5. Detrisac, C.J, Sens, M.A, Garvin, A.J, Spicer, S.S, Sens, D.A, Tissue culture of human kidney epithelial cells of proximal tubule origin, Kidney international ,1984, 25(2), 383-390.

6. Uysal, O, Sevimli, T, Sevimli, M, Gunes, S, Sariboyaci, A.E, Cell and Tissue Culture: The Base of Biotechnology, In: Omics Technologies and Bio-Engineering Towards Improving Quality of Life, 1st edn, Academic Press, London, 2018, 391-429.

7. Hendijani, F, Explant culture: An advantageous method for isolation of mesenchymal stem cells from human tissues, Cell proliferation, 2017, 50(2), e12334.

8. Valente, M.J, Henrique, R, Costa, V.L, Jerónimo, C, Carvalho, F, Bastos, M.L, Pinho, P.G, Carvalho, M, A rapid and simple procedure for the establishment of human normal and cancer renal primary cell cultures from surgical specimens, PloS one, 2011, 6(5), e19337.

9. Hawksworth, G.M, Isolation and culture of human renal cortical cells with characteristics of proximal tubules, Methods in Molecular Medicine, 2005, 107, 283-290.

10. Vesey, D.A, Qi, W, Chen, X, Pollock, C.A, Johnson, D.W, Isolation and primary culture of human proximal tubule cells, Methods in Molecular Biolology, 2009, 466, 19-24.

11. Glynne, P, Primary culture of human proximal renal tubular epithelial cells, Methods in Molecular Medicine, 2000, 36, 197-205.

12. Qian, T, Hernday, S, Bao, X, Olson, W.R, Panzer, S.E, Shusta, E.V, Palecek, S.P, Directed differentiation of human pluripotent stem cells to podocytes under defined conditions, Scientific reports,2019, 9(1), 1-12.

13. Satelli, A, Li, S, Vimentin in cancer and its potential as a molecular target for cancer therapy, Cellular and molecular life sciences, 2011, 68(18), 3033-3046.

14. Shen, S.S, Krishna, B, Chirala, R, Amato, R.J, Truong, L.D, Kidneyspecific cadherin, a specific marker for the distal portion of the nephron and related renal neoplasms. Modern pathology, 2005, 18(7), 933-940.

15. Sureshbabu, A, Muhsin, S.A, Choi, M.E, TGF- $\beta$ signaling in the kidney: profibrotic and protective effects, American Journal of Physiology-Renal Physiology, 2016, 310(7), F596-F606.

16. Bruno, S, Bussolati, B, Grange, C, Collino, F, Graziano, M.E, Ferrando, U, et al, CD133+ renal progenitor cells contribute to tumor angiogenesis, The American journal of pathology, 2006, 169(6), 2223-2235.

17. Shankland, S.J, Pippin, J.W, Reiser, J, Mundel, P. Podocytes in culture: past, present, and future. Kidney international, 2007,72(1), 26-36.

http://edergi.cbu.edu.tr/ojs/index.php/cbusbed isimli yazarın CBU-SBED başlıklı eseri bu Creative Commons Alıntı-Gayriticari4.0 Uluslararası Lisansı ile lisanslanmıştır.

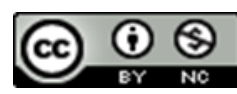

